\title{
Blood lactate levels of decathletes during competition
}

\author{
Pierre Beaulieu, Hélène Ottoz, Caroline Grange, Janice Thomas and Claude Bensch \\ Laboratoire de Biologie Appliquée à l'Education Physique et aux Sports, Université de Bordeaux 11, 146 rue Léo \\ Saignat, 33076 Bordeaux cedex, France
}

\begin{abstract}
There are many detailed physiological profiles of athletes who participate in a wide variety of sporting activities but few data have been obtained on decathletes. This study defines some physiological characteristics of these athletes and measures capillary lactate concentrations [ $\left[\mathrm{a}_{b}\right]$ during a laboratory test of progressive maximal exhaustion and the different events during competition. The treadmill test is similar to the $100 \mathrm{~m}, 400 \mathrm{~m}$ and $1500 \mathrm{~m}$ in terms of [Lab] accumulation but only similar to the $1500 \mathrm{~m}$ in terms of velocity. The $400 \mathrm{~m}$ is the most demanding event with the greatest blood lactate accumulation (mean(s.d.) 16.38(2.36) mmoll ${ }^{-1}$ ). The $\left[\mathrm{La}_{b}\right]$ at the end of the $110 \mathrm{~m}$ hurdles is significantly lower than in any other racing events (mean(s.d.) 6.96(1.32) mmol $^{-1}$ ) compared with mean(s.d.) 12.14(2.87) and mean(s.d.) $11.44(2.16)$ for the $100 \mathrm{~m}$ and $1500 \mathrm{~m}$ respectively. The [ $\left[\mathrm{a}_{b}\right]$ after the long jump, the high jump and the pole vault are not significantly different (mean(s.d.) 5.30(2.23), 4.64(1.39) and 5.36(1.34) mmol $^{-1}$ ) respectively).
\end{abstract}

Keywords: sports physiology, lactate, anaerobic threshold, track and field

The decathlon is an athletic competition extending over two days and includes four track and six field events. The order of events are, on the first day: 100 metres, long jump, shot put, high jump, and 400 metres; on the second day: 110 metres hurdles $(110 \mathrm{mH})$, discus throw, pole vault, javelin, and 1500 metres. The decathlon was first introduced by the Greeks $(708 \mathrm{BC})$ as a five event competition to venerate the 'complete athlete'.

Although there are many physiological profiles of athletes participating in a wide variety of sporting events, few data are available on this select group of competitors ${ }^{1}$. The purpose of this investigation was to assess the physiological profiles and capillary lactate concentrations ([Lab]) of these athletes both in training and competition.

\section{Methods}

Seven male decathlon athletes (six competing at national level) were investigated during training at the Regional Institute of Sports Medicine of

Address for correspondence: Dr P. Beaulieu, 4800 Boulevard de Maisonneuve Ouest, \#515, Westmount, Québec, Canada H3Z 1M2
Bordeaux, France and then, again, one month later during an official competition (The Regional Combined Events Championship). Informed consent was obtained from the athletes prior to investigation. Table 1 shows the general characteristics of the subjects.

The tests performed in the laboratory included measurements of weight, height, skinfold measurements, spirometry, heart rate (electrocardiography), maximal $\mathrm{O}_{2}$ uptake $\left(\dot{V}_{2}{ }_{2}\right.$ ax $)$ and blood lactate during progressive exercise to exhaustion.

Skinfold measurements were taken at four sites (biceps, triceps, subscapular and suprailiac) using a skinfold caliper ${ }^{2}$. The respiratory function tests were measured with an electronic spirometer (Fukuda CSA 800, Japan) and consisted of the following: forced vital capacity (FVC), forced expiratory volume in one second $\left(\mathrm{FEV}_{1}\right)$, peak expiratory flow rate (PEFR) and maximum breathing capacity (MBC). The maximum oxygen uptake was measured indirectly on a cycle ergometer (Siemens Elema, Germany), as described by Astrand ${ }^{3}$, with work rate increments of $20 \mathrm{~W}$ every 2 min until a stable heart rate of $150 \mathrm{bpm}$ was obtained. This test was chosen because it served as a warming up period before undergoing (approximately $20 \mathrm{~min}$ later) the treadmill exercise which then lead to complete exhaustion.

The progressive exercise test was performed on a treadmill (Serres, France) with an initial speed of $8 \mathrm{~km} \mathrm{~h}^{-1}$ (slope $3 \%$ ) and increased every $2 \mathrm{~min}(10$, $12,14,16,18,18$ [slope $6 \%$ ] $\mathrm{km} \mathrm{h}^{-1}$ ), with 1 min rest between each level, until complete exhaustion.

The continuous heart rate of each athlete was measured during both the determination of the $\dot{V} \mathrm{O}_{2 \max }$ and the progressive exercise using Holter's method $^{4}$.

Samples of free flowing arterialized capillary blood were obtained from the extremity of a finger using an Autolet (a device used for drawing blood). Arterial lactate appears to be preferable to venous lactate because it is not contaminated by the effect of resting muscle lactate metabolism ${ }^{5}$. Blood lactate concentration was obtained using a lactate electrode (Sétric Génie Industriel, France). It was measured first at rest, then during the $1 \mathrm{~min}$ interval at each treadmill level and finally $3 \mathrm{~min}$ after the end of the test, giving six to eight measures for each athlete.

It has been shown that lactate diffuses from the muscles and has a peak plasma concentration 
Table 1. Subject's characteristics

\begin{tabular}{|c|c|c|c|c|c|c|}
\hline Subject & Age $(y r)$ & Height $(\mathrm{cm})$ & Weight (kg) & Fat (\%) & Heart rate (rest) bpm & $\dot{V}_{O_{2 \max }}(\mathrm{m} / / \mathrm{kg} / \mathrm{min})$ \\
\hline 1 & 28 & 182 & 74.6 & 15.13 & 56 & 52.82 \\
\hline 2 & 21 & 185 & 73.1 & 8.97 & 68 & 51.22 \\
\hline 3 & 24 & 191 & 89.4 & 12.56 & 51 & 49.71 \\
\hline 4 & 18 & 181.5 & 72.4 & 14.56 & 51 & 45.81 \\
\hline 5 & 21 & 177 & 75.2 & 12.98 & 46 & 60.85 \\
\hline 6 & 19 & 175 & 66.5 & 11.09 & 76 & 49.41 \\
\hline & 21 & 178.5 & 71.9 & 10.39 & 56 & 54.97 \\
\hline Mean(s.d.) & $21.71(3.35)$ & $181.43(5.39)$ & $74.73(7.06)$ & $12.24(2.23)$ & $57.71(10.59)$ & $52.11(4.81)$ \\
\hline
\end{tabular}

Table 2. Spirometry measurements

\begin{tabular}{lcccc}
\hline Subject & $\begin{array}{c}\text { Forced } \\
\text { vital } \\
\text { capacity } \\
(I)\end{array}$ & $\begin{array}{c}\text { Forced } \\
\text { expiratory } \\
\text { volumein } \\
1 \text { s }(I)\end{array}$ & $\begin{array}{c}\text { Maximum } \\
\text { breathing } \\
\text { capacity } \\
(I / \text { min) }\end{array}$ & $\begin{array}{c}\text { Peak } \\
\text { expiratory } \\
\text { flowrate } \\
(I / s)\end{array}$ \\
\hline 1 & 5.78 & 4.77 & 175.20 & 10.53 \\
2 & 5.43 & 4.69 & 190.82 & 10.23 \\
3 & 6.05 & 5.27 & 181.64 & 8.98 \\
4 & 4.69 & 4.22 & 131.45 & 9.05 \\
5 & 4.80 & 3.98 & 130.66 & 7.86 \\
6 & 4.77 & 3.79 & 157.27 & 10.30 \\
7 & 4.73 & 3.63 & 105.27 & 7.15 \\
Mean(s.d.) & $5.18(0.57)$ & $4.34(0.59)$ & $153.19(31.63)$ & $9.16(1.3)$ \\
\hline
\end{tabular}

between 3 and $6 \mathrm{~min}$ after the end of an exercise ${ }^{6-8}$. [ $\mathrm{La}_{\mathrm{b}}$ ] was measured $3 \mathrm{~min}$ after each event except for the $400 \mathrm{~m}$, where it was measured at $6 \mathrm{~min}$ after the event (higher $\left[\mathrm{La}_{b}\right]$ were expected in this event). During the competition $\left[\mathrm{La}_{\mathrm{b}}\right]$ measurements were made at rest (after a short warm-up period) at the beginning of each day and then as follows:

First day: $3 \mathrm{~min}$ after the $100 \mathrm{~m}, 3 \mathrm{~min}$ after the long jump, before the $400 \mathrm{~m}$ (after the high jump), $6 \mathrm{~min}$ after the $400 \mathrm{~m}, 20 \mathrm{~min}$ after the $400 \mathrm{~m}$; and on the second day: $3 \mathrm{~min}$ after the $110 \mathrm{~m}$ hurdles, $3 \mathrm{~min}$ after the pole vault, before the $1500 \mathrm{~m}, 3 \mathrm{~min}$ after the $1500 \mathrm{~m}$ and $20 \mathrm{~min}$ after the $1500 \mathrm{~m}$.

The statistical analyses were performed using StatView and SPSS. The paired $t$ test was used to compare data within our group of decathlon athletes and the unpaired $t$ test for data between the two groups (Faris and ours). $P<0.05$ was considered statistically significant. Results are presented as mean(s.d.).

\section{Results}

The clinical examination and the electrocardiographic recordings of the athletes were all within normal limits. The mean(s.d.) bradycardia, 57.7(10.5) bpm, of normal athletes in training was noted. These athletes (mean age 21) had a mean(s.d.) $\dot{V} \mathrm{O}_{2 \max }$ of $52.11(4.81)$ $\mathrm{ml} \mathrm{min}-1 \mathrm{~kg}^{-1}$. Table 2 gives the results of the respiratory function tests.

The values of heart rate and [ $\left[a_{b}\right]$ during the treadmill exercise are given in Tables 3 and 4 respectively. The mean(s.d.) maximal heart rate achieved was 195(5.37) bpm and mean(s.d.) maximal $\left[\mathrm{La}_{\mathrm{b}}\right]$ reached was $14.15(2.34) \mathrm{mmoll}^{-1}$. Figure 1 shows heart rate and blood lactate measurements against different powers of exercise on the treadmill.

The individual values of the $\left[\mathrm{La}_{b}\right]$ during competition are given in Table 5. The maximum mean(s.d.) [Lab] is obtained $6 \mathrm{~min}$ after the $400 \mathrm{~m}(16.38(2.36)$

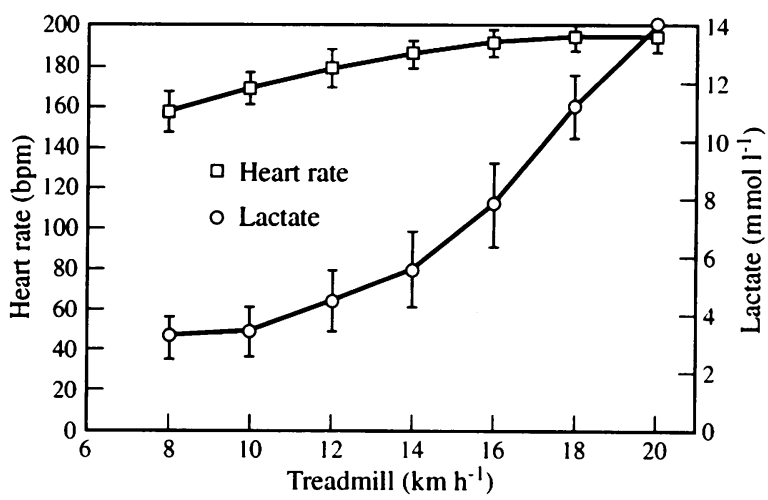

Figure 1. Mean(s.d.) heart rate and blood lactate measurements against different powers of exercise on the treadmill

Table 3. Heart rates

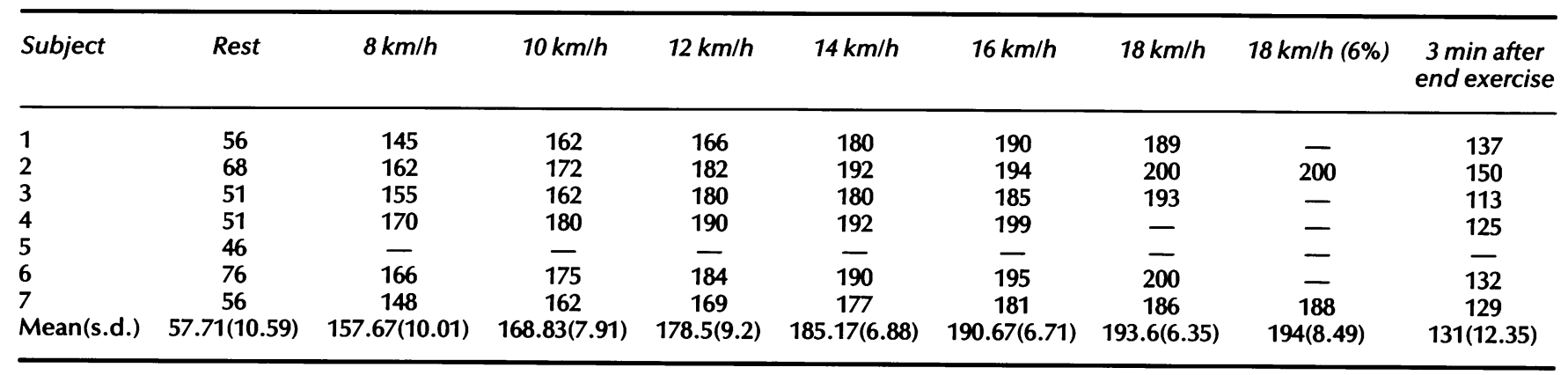


Table 4. Blood lactates

\begin{tabular}{|c|c|c|c|c|c|c|c|c|c|}
\hline Subject & Rest & $8 \mathrm{~km} / \mathrm{h}$ & $10 \mathrm{~km} / \mathrm{h}$ & $12 \mathrm{~km} / \mathrm{h}$ & $14 \mathrm{~km} / \mathrm{h}$ & $16 \mathrm{~km} / \mathrm{h}$ & $18 \mathrm{~km} / \mathrm{h}$ & $18 \mathrm{~km} / \mathrm{h}(6 \%)$ & $\begin{array}{l}3 \text { min after } \\
\text { end exercise }\end{array}$ \\
\hline 1 & 0.73 & 3.22 & 4.54 & 3.61 & 4.61 & 8.34 & 12.08 & - & 9.96 \\
\hline 2 & 0.54 & 4.10 & 4.17 & 5.40 & 5.37 & 6.70 & 11.23 & 14.17 & 17.51 \\
\hline 3 & 0.86 & 2.27 & 2.42 & - & 7.32 & 8.16 & 12.38 & - & 16.68 \\
\hline 4 & 1.75 & - & 3.61 & 5.84 & 7.32 & 10.26 & - & - & 12.44 \\
\hline 5 & - & - & - & - & - & - & - & - & - \\
\hline 6 & 0.98 & 4.03 & 3.42 & 3.46 & 5.80 & 7.02 & 9.94 & - & 12.69 \\
\hline 7 & 1.04 & 2.97 & 2.44 & - & 4.43 & 6.21 & 10.25 & 13.49 & 13.42 \\
\hline Mean(s.d.) & $0.98(0.42)$ & $3.24(0.71)$ & $3.43(0.87)$ & $4.50(1.07)$ & $5.62(1.27)$ & $7.78(1.47)$ & $11.18(1.08)$ & $13.83(0.48)$ & $13.78(2.83)$ \\
\hline
\end{tabular}

Table 5. Blood lactate levels during competition

\begin{tabular}{|c|c|c|c|c|c|c|c|c|c|c|c|c|}
\hline Subject & $\begin{array}{l}1^{\circ} \text { day } \\
\text { rest }\end{array}$ & $\underset{100 \mathrm{~min}}{3 \mathrm{~m}}$ & $\begin{array}{c}3 \mathrm{~min} \\
\text { after long } \\
\text { jump }\end{array}$ & $\begin{array}{l}\text { Before } \\
400 \mathrm{~m}\end{array}$ & $\begin{array}{l}6 \mathrm{~min} \\
\text { after } \\
400 \mathrm{~m}\end{array}$ & $\begin{array}{c}20 \mathrm{~min} \\
\text { after } \\
400 \mathrm{~m}\end{array}$ & $\begin{array}{l}2^{\circ} \text { day } \\
\text { rest }\end{array}$ & $\begin{array}{c}3 \mathrm{~min} \\
\text { after } \\
110 \mathrm{mH}\end{array}$ & $\begin{array}{l}3 \text { min } \\
\text { after } \\
\text { pole } \\
\text { vault }\end{array}$ & $\begin{array}{l}\text { Before } \\
1500 \mathrm{~m}\end{array}$ & $\begin{array}{c}3 \mathrm{~min} \\
\text { after } \\
1500 \mathrm{~m}\end{array}$ & $\begin{array}{c}20 \mathrm{~min} \\
\text { after } \\
1500 \mathrm{~m}\end{array}$ \\
\hline 1 & 3.20 & 12.83 & 6.13 & 6.03 & 18.57 & 9.18 & - & 9.28 & 7.32 & 6.44 & 8.20 & 1.30 \\
\hline 2 & 1.51 & 17.06 & 2.33 & 3.58 & 16.75 & 7.78 & 2.05 & 6.80 & 4.77 & 4.50 & 14.04 & 3.37 \\
\hline 3 & 2.73 & 10.41 & 3.86 & 2.63 & 15.95 & 9.47 & 1.92 & 7.64 & 5.72 & 2.69 & 10.75 & 3.81 \\
\hline 4 & 1.53 & 11.07 & 3.46 & 6.50 & 12.38 & 5.21 & 2.74 & 6.07 & - & - & - & - \\
\hline 6 & 3.20 & 14.03 & 8.54 & 5.43 & 17.65 & 9.29 & 3.13 & 5.01 & 6.03 & 3.26 & 13.52 & 4.72 \\
\hline 7 & 2.45 & 8.07 & 7.36 & 4.20 & 18.96 & 7.45 & 2.88 & 7.10 & 4.96 & 1.24 & 11.81 & 3.83 \\
\hline Mean(s.d.) & $2.40(0.71)$ & $12.14(2.87)$ & $5.30(2.23)$ & $4.64(1.39)$ & $16.38(2.36)$ & $7.88(1.57)$ & $2.61(0.50)$ & $6.96(1.32)$ & $5.36(1.34)$ & $3.47(1.79)$ & $11.44(2.16)$ & $3.72(1.38)$ \\
\hline
\end{tabular}

mmoll ${ }^{-1}$ ). $95 \%$ confidence intervals for lactate concentration for the four races and the maximal values obtained in the laboratory are presented in Table 6.

\section{Discussion}

The general characteristics of our athletes compared with a group of nine world class decathlon athletes ${ }^{1}$ show that they are on average younger (21.7 versus 27.2 years $[P=0.009])$ and much lighter $(74.7$ versus $84.7 \mathrm{~kg}[P=0.004])$ but have similar height $(181.4$ versus $183.9 \mathrm{~cm}[P=0.28])$, and have similar percentages of fat (12.2 versus 12.8 [ $P=0.66]$, vital capacities (5.18 versus 5.161$)$ and $\dot{V}_{\mathrm{O}_{2} \max }(52.1$ versus 57.6 $[P=0.20])$. The difference in weight may be due to more emphasis on weight lifting in the world class athletes and more years spent in training. The maximum oxygen uptake in the 50-60 range, is what is expected in explosive (non-endurance) athletes.

In the same study, Faris et al. ${ }^{1}$ analysed body build using anthropometric fractionation and stated that 'the most outstanding features of anthropometric fractionation appear to be very large biceps and small abdomens' (94.0 and $74.4 \mathrm{~cm}$ respectively).

Table 6. 95\% confidence intervals of blood lactate concentrations for treadmill test and races

\begin{tabular}{lc}
\hline Laboratory test & 10.81 to $16.75 \mathrm{mmoll}^{-1}(2.97)$ \\
$100 \mathrm{~m}$ & 9.48 to $14.79 \mathrm{mmoll}^{-1}(2.65)$ \\
$400 \mathrm{~m}$ & 14.2 to $18.56 \mathrm{mmoll}^{-1}(2.18)$ \\
$110 \mathrm{mH}$ & 5.74 to $8.19 \mathrm{mmoll}^{-1}(1.22)$ \\
$1500 \mathrm{~m}$ & 9.17 to $13.71 \mathrm{mmoll}^{-1}(2.27)$
\end{tabular}

Blood lactate levels may provide a useful indication of the energy derived from anaerobic glycolysis during exercise. In the decathlon, lactate values obtained at the end of each event could be an important indication of the contribution of anaerobic mechanisms to the total energy requirements ${ }^{6}$.

The $\left[\mathrm{La}_{b}\right]$ during the competition showed four peaks, which were, in order of magnitude, (1) the $400 \mathrm{~m}$ is the most demanding event and therefore incurs the greatest lactate accumulation; $6 \mathrm{~min}$ after the $400 \mathrm{~m}$, mean(s.d.) $\left[\mathrm{La}_{\mathrm{b}}\right]=16.38(2.36) \mathrm{mmoll}^{-1}$. Other workers ${ }^{9,10}$ have found that $400 \mathrm{~m}$ athletes have higher $\left[\mathrm{La}_{b}\right]$ after exhaustion tests than runners from other specialities. [ $\mathrm{La}_{\mathrm{b}}$ ] of 16 to $17 \mathrm{mmoll}^{-1}$ have been found in these runners ${ }^{8,11}$; (2) after $100 \mathrm{~m}$, mean(s.d.) $\left[\mathrm{La}_{\mathrm{b}}\right]=12.14(2.87) \mathrm{mmoll}^{-1}$. One author ${ }^{11}$ found mean(s.d.) [ $\left[\mathrm{La}_{\mathrm{b}}\right.$ ] of $8.9(1.3) \mathrm{mmoll}^{-1}$ in athletes with a lower level of performance at the $100 \mathrm{~m}$; (3) after the $1500 \mathrm{~m}$, mean(s.d.) $\left[\mathrm{La}_{\mathrm{b}}\right]=$ $11.44(2.16) \mathrm{mmoll}^{-1}$; (4) following the $110 \mathrm{mH}$ mean(s.d.) $\left[\mathrm{La}_{\mathrm{b}}\right], 6.96(1.32) \mathrm{mmoll}^{-1}$. This very technical event, longer in time and distance than the $100 \mathrm{~m}$, is associated with significantly $(P=0.018)$ lower blood lactate values. This could be explained by lower running speed during the event as shown below.

When considering only the races, it is possible to look at the peak $\left[\mathrm{La}_{\mathrm{b}}\right]$ according to the running speed (velocity) of the athlete during the competition (in other terms the performance of the athlete for each race) (Figure 2); the data from the progressive exhaustion test in the laboratory are also plotted. Four groups are identified. Although the fastest race (around $9 \mathrm{~m} \mathrm{~s}^{-1}$ ), the $100 \mathrm{~m}$ lasted just above $11 \mathrm{~s}$ on average and blood lactate values are in the 


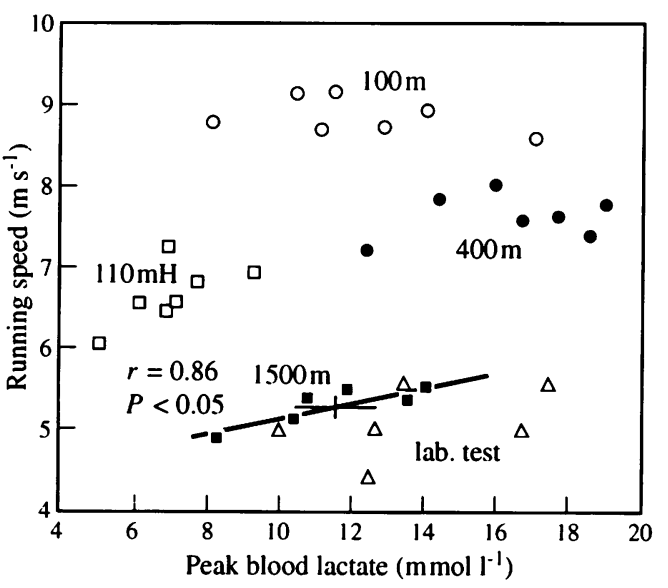

Figure 2. Relationship between peak blood lactate and running speed of the $100 \mathrm{~m}, 400 \mathrm{~m}, 110 \mathrm{mH}$ and $1500 \mathrm{~m}$, and the laboratory test

$12 \mathrm{mmoll}^{-1}$ range. As discussed above, the $110 \mathrm{mH}$ was performed at a lower speed $\left(6.68 \mathrm{~m} \mathrm{~s}^{-1}\right.$ on average) than the $100 \mathrm{~m}$. In the $400 \mathrm{~m}$, the highest peak $\left[\mathrm{La}_{\mathrm{b}}\right]$ can be explained by a velocity of nearly $8 \mathrm{~m} \mathrm{~s}^{-1}$ but this was maintained for 49 to $55 \mathrm{~s}$. The $1500 \mathrm{~m}$ and the test performed in the laboratory seemed to be very similar in terms of velocity and blood lactate values. Peak blood lactate was found to correlate significantly with running speed for the $1500 \mathrm{~m}(r=0.86, P<0.05)$. In the other races and the laboratory test, it failed to attain statistical significance.

A paired $t$ test was used to compare the laboratory results with the results of the races $(100 \mathrm{~m}, 400 \mathrm{~m}$, $110 \mathrm{mH}$ and $1500 \mathrm{~m}$ ). The only significant difference was in the $110 \mathrm{mH}(P=0.005)$. We corrected for multiple significance testing by using the Bonferroni correction ${ }^{12}$.

The highest $\left[\mathrm{La}_{b}\right]$ before the races was before the $400 \mathrm{~m}\left(4.64 \mathrm{mmoll}^{-1}\right.$ versus $2.40,2.61,3.47 \mathrm{mmoll}^{-1}$ before the $100 \mathrm{~m}, 110 \mathrm{mH}$ and $1500 \mathrm{~m}$ respectively) and this is significantly different. One athlete had a $\left[\mathrm{La}_{\mathrm{b}}\right]$ of $6.44 \mathrm{mmoll}^{-1}$ before the $1500 \mathrm{~m}$ and it is interesting to note that he was the one who performed best at pole vault, and therefore had the least time to recover between the last three events and who finally had the worst performance at the $1500 \mathrm{~m}\left(5^{\prime} 05^{\prime \prime} 97\right)$ and had the least increase in blood lactate at the end of this event!

The $\left[\mathrm{La}_{\mathrm{b}}\right]$ at the beginning of each day (mean of 2.40 and $2.61 \mathrm{mmoll}^{-1}$ ) may seem already high following only a warm-up period, but similar values were reported by De Saedeleer et al. ${ }^{11}$ in sprinters.

The mean(s.d.) [ $\left.\mathrm{La}_{\mathrm{b}}\right]$ after the three jumps, $5.30(2.23), 4.64(1.39)$ and $5.36(1.34) \mathrm{mmoll}^{-1}$ were not significantly different. Adenosine triphosphate (ATP) and creatine phosphate (CP) stores are probably depleted in 3-5s when the effort is maximal. For the long jump and the pole vault, repeated sprints of $30-40 \mathrm{~m}$ are usual and this may explain why the ATP and PC stores may not provide all the energy required, and the moderate lactate accumulation of $5 \mathrm{mmoll}^{-1}$ seen.
The actual protocol did not allow us to assess the throws, with the exception of the javelin. The $\left[\mathrm{La}_{b}\right]$ values recorded before the $1500 \mathrm{~m}$ were in fact taken shortly after the end of the javelin (only $30 \mathrm{~min}$ separated the end of the javelin from the start of the $1500 \mathrm{~m}$ ). It seems unlikely that the throws are associated with marked increases in [ $\mathrm{La}_{\mathrm{b}}$ ], especially for the shot and the discus (efforts of less than $3 \mathrm{~s}$ with utilization of high-energy phosphates). The javelin is expected to be more demanding in terms of energy expenditure, but probably not sufficient to see a significant increase in $\left[\mathrm{La}_{\mathrm{b}}\right]$. The mean(s.d.) levels of blood lactate found after this event (3.47[1.79] mmoll ${ }^{-1}$ ), measured within $1 \mathrm{~h}$ after the end of the pole vault, may correspond to decreasing blood lactate from this event.

Controversy exists concerning the change of $\left[\mathrm{La}_{b}\right]$ with increasing levels of exercise in $\operatorname{man}^{13-16}$. The anaerobic threshold (AT), also called 'onset of blood lactate accumulation' (OBLA), is for some identified as the work-rate (running speed in our study) at which blood lactate reaches $4 \mathrm{mmoll}^{-1}$ in an incremental test ${ }^{17}$. For others $\left[\mathrm{La}_{b}\right]$ increases as a continuous function in progressive exercises $5,14,18,19$ and does not behave as a threshold phenomenon where $\left[\mathrm{La}_{\mathrm{b}}\right]$ suddenly increases at a critical work rate 16,19-21.

The determination of the AT in our athletes has been done using the techniques described by Orr and Green ${ }^{22,23}$ : the AT is determined from individual plots of blood lactate and power output where a breakaway point is calculated using the technique of linear regression. A regression line was fitted through the three lowest energy levels $(8,10$, $12 \mathrm{~km} \mathrm{~h}^{-1}$ ) and the significance of the slope assessed. If not significant, progressively higher energy levels were added to the data and another regression line fitted. This process was repeated until a significant slope was found. In our study, the slope changed from non-significance to significance between 12 and $14 \mathrm{~km} \mathrm{~h}^{-1}(P=0.04)$.

At these levels of exercise, namely 12 and $14 \mathrm{~km} \mathrm{~h}^{-1}$, the mean(s.d.) corresponding heart rate was $178.5(9.2)$ and $185.17(6.88) \mathrm{bpm}$ and the mean(s.d.) [Lab] $4.50(1.07)$ and $5.62(1.27) \mathrm{mmol}^{-1}$. These values are much less than those found in middle and long-distance international athlete ${ }^{24,25}$ (AT at $18 \mathrm{~km} \mathrm{~h}^{-1}$ and heart rate of $176 \mathrm{bpm}$ ). However, this is to be expected because decathletes, due to their specific training and performance, are physiologically closer to sprinters than endurance athletes. It has been shown that with endurance training these curves of lactate accumulation with progressive increase in exercise are shifted to the right 24,25 .

Finally there is no significant difference between the $\left[\mathrm{La}_{\mathrm{b}}\right]$ measured on the first day before the competition started (after a warming up period) and $20 \mathrm{~min}$ after the $1500 \mathrm{~m}$ at the end of the second day, following an active recovery period (mean(s.d.) difference $\left.1.32 \mathrm{mmoll}^{-1}(0.53)\right)(P>0.1)$.

The progressive exhaustion test on the treadmill, performed in the laboratory, can help to estimate the increase of lactic acid in the blood during competition. It gives a profile of peak values of $\left[\mathrm{La}_{b}\right]$, which is 
statistically not significantly different from that of the $100 \mathrm{~m}, 400 \mathrm{~m}$ and $1500 \mathrm{~m}$ respectively, and it was run at similar velocity with the $1500 \mathrm{~m}$. The decathlon, with a series of races, jumps and throws throughout the two days of competition, stimulates both the aerobic and anaerobic pathways. Lactate production in this setting is complex and is not assessed satisfactorily using only intermittent blood lactate mesurements. However, the ability to produce lactate is essential for high intensity efforts ${ }^{7}$.

It is hoped this study may help gain a better physiological understanding of $\left[\mathrm{La}_{b}\right]$ variations during a decathlon.

\section{Acknowledgements}

We wish to thank the athletes who participated in this study and their coach Pierre Darrière.

\section{References}

1 Faris AW, Giley WF, Dean GM, Teh KC. Physiological profiles of world class decathlon athletes in training. J Sports Med 1980; 20: 285-90.

2 Durnin JVGA, Rahaman MM. The assessment of the amount of fat in the human body from measurements of skinfold thickness. Br J Nutr 1967; 21: 681-9.

3 Åstrand I. Aerobic work capacity in men and women with special reference to age. Acta Physiol Scand 1960; 49(Suppl. 169).

4 Holter NJ. New method for heart studies: continuous electrocardiography of active subjects over long periods is now practical. Science 1961; 134: 1214-20.

5 Yeh MP, Gardner RM, Adams TD, Yanowitz FG, Crapo RO. 'Anaerobic threshold': problems of determination and validation. J Appl Physiol 1983; 55: 1178-86.

6 Margaria R, Aghemo P, Sassi G. Lactic acid production in supramaximal exercise. Pflug Arch 1971; 326: 152-61.

7 Gollnick PD, Bayly WM, Hodgson DR. Exercise intensity, training, diet and lactate concentration in muscle and blood. Med Sci Sports Exerc 1986; 18: 334-40.

8 Medbø JI, Sejersted OM. Acid-base and electrolyte balance after exhausting exercise in endurance-trained and sprint- trained subjects. Acta Physiol Scand 1985; 125: 97-109.

9 Crielaard JM, Merken P, Franchimont P, Pirnay F, Petit JM. Evaluation de la capacité anaérobie lactique en athlétisme. Médecine du Sport 1986; 60: 15-239.

10 Schnabel A, Kindermann W. Assessment of anaerobic capacity in runners. Eur J Appl Physiol 1983; 52: 42-6.

11 De Saedeleer, M, De Bruyn P, Sturbois $X$. Evolution du taux de lactate sanguin lors d'un effort court et maximal sur le terrain. Médecine du Sport 1986; 60: 5, 3-227-6-230.

12 Armitage P, Berry G. Statistical Methods in Medical Research. Oxford, UK: Blackwell Scientific Publications, 1994: 331.

13 Beaver WL, Wasserman K, Whipp BJ. Improved detection of lactate threshold during exercise using a log-log transformation. J Appl Physiol 1985; 59: 1936-40.

14 Brooks GA. Anaerobic threshold review of the concept and directions for future research. Med Sci Sports Exerc 1985; 17: 22-31.

15 Gladden LB, Yates JW, Stremel RW, Stamford BA. Gas exchange and lactate anaerobic thresholds: inter and intra evaluator agreement. J Appl Physiol 1985; 58: 2082-9.

16 Jones LD, Ehrsam RE. The anaerobic threshold. Exerc Sport Sci Rev 1982; 14: 49-83.

17 Spurway NC. Aerobic exercise, anaerobic exercise and the lactate threshold. Br Med Bulletin 1992; 569-91.

18 Hughson RL, Weisiger KH, Swanson GD. Blood lactate concentration increases as a continuous function in progressive exercise. J Appl Physiol 1987; 62: 1975-81.

19 Stainsby WN, Sumners EW, Eitzman PD. Effects of catecholamines on lactic acid output during progressive working contractions. J Appl Physiol 1985; 59: 1809-14.

20 Connett RJ, Grayeski TEJ, Honig CR. Lactate accumulation in fully aerobic, working dog gracilis muscle. Am J Physiol 1984; 246: H120-H8.

21 Mazzeo RS, Brooks GA, Schoeller DA, Budinger TF. Disposal of blood $\left[1-{ }^{13} \mathrm{C}\right]$ lactate in humans during rest and exercise. $J$ Appl Physiol 1986; 60: 232-41.

22 Orr GW, Hughson RL, Green HJ, Bennett GW. A computer linear regression model for determination of ventilatory anaerobic threshold. J Appl Physiol 1982; 52: 1349-52.

23 Green HJ, Hughson RL, Orr GW, Ranney DA. Anaerobic threshold, blood lactate, and muscle metabolites in progressive exercise. J Appl Physiol 1983; 54: 1032-8.

24 Jousselin E, Handschuh R, Stephan H. Détermination de la zone de transition aérobie-anaérobie et utilisation pratique pour l'entrainement. Cinésiologie 1984; 23: 301-4.

25 Jousselin E, Handschuh R, Stephan H. Etude de la transition aérobie-anaérobie chez les coureurs de demi-fond français (hommes et femmes). Cinésiologie 1984; 23: 305-13. 